\title{
Effluviibacter roseus gen. nov., sp. nov., isolated from muddy water, belonging to the family 'Flexibacteraceae'
}

\author{
K. Suresh, S. Mayilraj and T. Chakrabarti \\ Microbial Type Culture Collection and Gene Bank (MTCC), Institute of Microbial Technology, \\ Sector 39A, Chandigarh - 160036 , India
}

Correspondence

T. Chakrabarti

tapan@imtech.res.in

\begin{abstract}
A Gram-negative bacterial isolate (designated SRC-1 ${ }^{\top}$ ) was isolated from an occasional drainage system and characterized by a polyphasic approach to determine its taxonomic position. Phylogenetic analysis based on $16 \mathrm{~S}$ rRNA gene sequences affiliated strain SRC-1 ${ }^{\top}$ with the family 'Flexibacteraceae' of the phylum Bacteroidetes. It showed greatest sequence similarity to Pontibacter actiniarum KMM $6156^{\top}$ (95.5\%) followed by Adhaeribacter aquaticus MBRG1.5 ${ }^{\top}$ (89.0\%) and Hymenobacter roseosalivarius DSM $11622^{\top}$ (88.9\%), but it differed from these micro-organisms in many phenotypic characteristics. Strain SRC-1 ${ }^{\top}$ was an obligate aerobe and its cells were non-motile, irregular rods. The major fatty acids included mainly unsaturated and hydroxy fatty acids, including $17: 1$ iso $\mathrm{l} /$ anteiso $\mathrm{B}(36 \cdot 7 \%), 15: 0$ iso $(15 \cdot 8 \%)$ and $17: 0$ iso $3-\mathrm{OH}$ $(10 \cdot 3 \%)$, and the DNA G +C content was 59.5 mol\%. From the phenotypic and genotypic analyses it was clear that strain SRC-1 ${ }^{\top}$ was quite different from members other genera in the family 'Flexibacteraceae'. Therefore we conclude that strain $\mathrm{SRC}-1^{\top}$ represents a novel genus, for which the name Effluviibacter gen. nov., containing a single species Effluviibacter roseus sp. nov., is proposed. The type species of the genus is Effluviibacter roseus, the type strain of which is strain SRC $-1^{\top}\left(=\right.$ MTCC $7260^{\top}=$ DSM $\left.17521^{\top}\right)$.
\end{abstract}

The Cytophaga-Flavobacterium-Bacteroides group of bacteria, now classified as the phylum Bacteroidetes (Garrity \& Holt, 2001), are widely distributed in diverse ecological niches. Although they are dominant in marine environments (Bowman et al., 1997), they are also found in soil, fresh water, in plants and in air (Buczolits et al., 2002). This phylum includes Gram-negative heterotrophic bacteria with the capacity to degrade complex polysaccharides such as agar, cellulose and chitin, and they play an important role in carbon cycling in the environment. This phylum includes three classes, one of which, the 'Sphingobacteria', includes five families: Sphingobacteriaceae, 'Saprospiraceae', 'Flexibacteraceae', 'Flammeovirgaceae' and Crenotrichaceae (Garrity \& Holt, 2001). The family 'Flexibacteraceae' is the largest of these, containing 10 genera with validly published names (Ludwig \& Klenk, 2001). A number of genera, including Pontibacter, Adhaeribacter, Algoriphagus, Belliella, Hongiella and Reichenbachiella (Nedashkovskaya et al., 2003, 2005; Rickard et al., 2005; Bowman et al., 2003; Bretter et al., 2004; Yi \& Chun, 2004), have been described recently as belonging to this family. In the present study, we have characterized a novel bacterium, strain SRC- $1^{\mathrm{T}}$, by using a polyphasic approach. On the basis of its morphological,

The GenBank/EMBL/DDBJ accession number for the $16 \mathrm{~S}$ rRNA gene sequence of strain $\mathrm{SRC}-1^{\top}$ is $\mathrm{AM} 049256$. biochemical, chemotaxonomic and genotypic characteristics, we conclude that the strain is quite distinct from existing genera within the family 'Flexibacteraceae' and merits classification within a novel genus.

Strain SRC- $1^{\mathrm{T}}$ was isolated from muddy water from an occasional drainage system of a residential area in Chandigarh, India. The sample was serially diluted in physiological saline $(\mathrm{NaCl}$ at $0.9 \%, \mathrm{w} / \mathrm{v})$, plated on nutrient agar medium ( $\mathrm{Hi}-$ media) and incubated at $30^{\circ} \mathrm{C}$. A small mucoid colony was observed upon prolonged incubation and it was purified. The strain was Gram-negative and could grow at temperatures between 4 and $37^{\circ} \mathrm{C}$, the optimum being $30^{\circ} \mathrm{C}$. On nutrient agar at $30^{\circ} \mathrm{C}$, colonies were circular, slightly shiny, mucoid and deep pink in colour. Cells of strain SRC- $1^{\mathrm{T}}$ were observed under a phase-contrast microscope (Axiophot; Zeiss) using an oil-immersion objective $(\times 100)$ to ascertain the shape and motility of the cells.

Physiological tests, including analysis of growth at different temperatures, $\mathrm{pH}$ values and salt concentrations, were done using nutrient agar medium. For the various biochemical analyses listed in Table 1 and in the species description, the culture was grown at $30{ }^{\circ} \mathrm{C}$ in nutrient broth and the tests were performed as described by Lanyi (1987) and Smibert \& Krieg (1994). In addition, the ability of strain SRC- $1^{\mathrm{T}}$ to utilize carbon compounds as sole carbon and energy sources 
Table 1. Comparison of biochemical characteristics of strain SRC-1 ${ }^{\top}$ with those of closely related bacteria

Strains: 1, strain SRC-1 ${ }^{\mathrm{T}}$; 2, P. actiniarum KMM $6156^{\mathrm{T}}$ (data from Nedashkovskaya et al., 2005); 3, Adhaeribacter aquaticus MBRG1.5 ${ }^{\mathrm{T}}$ (Rickard et al., 2005); 4, H. roseosalivarius DSM $11622^{\mathrm{T}}$ (Hirsch et al., 1998; Buczolits et al., 2002). NR, Not reported; W, weakly positive. All four strains are negative for nitrate reduction.

\begin{tabular}{|c|c|c|c|c|}
\hline Characteristic & 1 & 2 & 3 & 4 \\
\hline Colony colour & Pink & Pink & Pink & Rose \\
\hline Cell shape & Irregular rod & Rod & Rod & Rod \\
\hline Gliding motility & - & + & - & - \\
\hline \multicolumn{5}{|l|}{ Growth at: } \\
\hline $4{ }^{\circ} \mathrm{C}$ & + & - & + & + \\
\hline $42^{\circ} \mathrm{C}$ & - & + & - & NR \\
\hline Growth on $8.0 \% \mathrm{NaCl}$ & + & + & - & - \\
\hline Methyl red test & + & NR & NR & NR \\
\hline Casein hydrolysis & + & - & NR & + \\
\hline Starch hydrolysis & + & - & - & + \\
\hline \multicolumn{5}{|l|}{ Carbohydrate utilization } \\
\hline Adonitol & - & - & + & - \\
\hline D-Fructose & + & - & + & - \\
\hline myo-Inositol & - & - & + & - \\
\hline Lactose & + & - & - & W \\
\hline Acid production from glucose & + & - & - & NR \\
\hline \multicolumn{5}{|l|}{ Amino acid assimilation } \\
\hline Alanine & - & + & + & - \\
\hline Histidine & + & - & + & - \\
\hline Isoleucine & + & NR & + & NR \\
\hline Lysine & + & NR & + & NR \\
\hline Methionine & - & NR & + & NR \\
\hline Glycine & + & NR & + & NR \\
\hline \multicolumn{5}{|l|}{ Antibiotic sensitivity ${ }^{*}$} \\
\hline Gentamicin & S & $\mathrm{R}$ & S & NR \\
\hline Streptomycin & S & $\mathrm{R}$ & NR & NR \\
\hline DNA G $+\mathrm{C}$ content $(\mathrm{mol} \%)$ & $59 \cdot 5$ & $48 \cdot 7$ & $40 \cdot 0$ & $56 \cdot 0$ \\
\hline Phospholipids $\dagger$ & PG, DPG, UK1 & NR & NR & PE, DPG (trace) \\
\hline
\end{tabular}

${ }^{\star} \mathrm{S}$, Sensitive; R, resistant.

$\dagger$ PE, Phosphatidylethanolamine; PG, phosphatidylglycerol; DPG, diphosphatidylglycerol; UK1, unknown phospholipid.

was determined in medium [1.05\% (w/v) $\mathrm{K}_{2} \mathrm{HPO}_{4}, 0 \cdot 45 \%$ $(\mathrm{w} / \mathrm{v}) \mathrm{KH}_{2} \mathrm{PO}_{4}, 0 \cdot 1 \%(\mathrm{w} / \mathrm{v})\left(\mathrm{NH}_{4}\right)_{2} \mathrm{SO}_{4}$ and $1 \cdot 5 \%(\mathrm{w} / \mathrm{v})$ agarose] supplemented with $0.5 \%(\mathrm{w} / \mathrm{v})$ of each filtersterilized carbon compound. Assimilation of various amino acids as sole nitrogen sources was determined in a medium containing $1 \%(\mathrm{w} / \mathrm{v})$ D-glucose, $0.05 \%$ (w/v) $\mathrm{MgSO}_{4} \cdot 7 \mathrm{H}_{2} \mathrm{O}, 0.05 \%(\mathrm{w} / \mathrm{v}) \mathrm{NaCl}, 0.001 \%(\mathrm{w} / \mathrm{v})$ $\mathrm{Fe}_{3} \mathrm{SO}_{4} \cdot 7 \mathrm{H}_{2} \mathrm{O}, 0 \cdot 1 \%$ (w/v) $\mathrm{K}_{2} \mathrm{HPO}_{4}$ and $1 \cdot 5 \%$ (w/v) agarose, supplemented with the amino acid $(0 \cdot 2 \%$, w/v) being tested. Nutrient agar with antibiotic discs (Hi-Media) was used for checking the sensitivity of strain SRC $-1^{\mathrm{T}}$ to different antibiotics. Cellular fatty acid methyl esters were extracted and analysed using the Microbial Identification System (MIDI) as described previously (Pandey et al., 2002). Isoprenoid quinones were extracted according to the method described by Collins et al. (1977) and identified as described by Tamaoka et al. (1983) and Suresh et al. (2004b). Extraction of polar lipids and analysis of phospholipids were done as described previously (Suresh et al., 2004a). DNA was isolated as described by Shivaji et al. (1989). The G + C content of genomic DNA was estimated spectrophotometrically (Lambda 35; Perkin Elmer) as described by Mandel \& Marmur (1968).

Details of the phenotypic and chemotaxonomic characteristics of SRC- $1^{\mathrm{T}}$ are given in the genus and species descriptions. Strain SRC $-1^{\mathrm{T}}$ was strictly aerobic and the cells were Gram-negative, non-motile, irregular rods (Table 1). The fatty acid profile was dominated by unsaturated and hydroxy fatty acids, including 17:1 iso I/anteiso B (summed feature 
4) $(36 \cdot 7 \%), 15: 0$ iso $(15 \cdot 8 \%)$ and $17: 0$ iso $3-\mathrm{OH}(10 \cdot 3 \%)$ (Table 2). The presence of the fatty acid 15:0 iso has been reported for many genera belonging to the family 'Flexibacteraceae'; in strain SRC- $1^{\mathrm{T}}$, it constituted the second largest component of the total cellular fatty acid content. The polar lipids in strain SRC $-1^{\mathrm{T}}$ were phosphatidylglycerol, diphosphatidylglycerol and an unknown phospholipid. The DNA $\mathrm{G}+\mathrm{C}$ content was $59 \cdot 5 \mathrm{~mol} \%$.

The 16S rRNA gene sequence of strain SRC- $1^{\mathrm{T}}$ was amplified by a PCR using primers 8 -27f ( $5^{\prime}$-AGAGTTTGATCCTGGCTCAG-3') and 1492r (5'-TACGGYTACCTTGTTACGACTT-3'), as described by Pandey et al. (2002); the PCR product was purified using the QIAquick PCR purification kit (Qiagen). The purified amplicon was sequenced using the BigDye Terminator cycle sequencing kit and an ABI PRISM model 310 automatic DNA sequencer (Applied Biosystems). The $16 \mathrm{~S}$ rRNA gene sequences of type species of genera of the 'Flexibacteraceae' with validly published names were retrieved from the EMBL database, aligned with

Table 2. Fatty acid profiles of strain $\mathrm{SRC}-1^{\top}$ and closely related strains

Strains: 1, strain SRC-1 ${ }^{\mathrm{T}}$; 2, P. actiniarum $\mathrm{KMM} 6156^{\mathrm{T}}$ (data from Nedashkovskaya et al., 2005); 3, Adhaeribacter aquaticus MBRG1.5 ${ }^{\mathrm{T}}$ (Rickard et al., 2005); 4, H. roseosalivarius DSM $11622^{\mathrm{T}}$ (Buczolits et al., 2002). -, Absent; NR, not reported.

\begin{tabular}{|lccrc|}
\hline Fatty acid & $\mathbf{1}$ & $\mathbf{2}$ & $\mathbf{3}$ & $\mathbf{4}$ \\
\hline $14: 0$ iso & $0 \cdot 8$ & $\mathrm{NR}$ & $\mathrm{NR}$ & $\mathrm{NR}$ \\
$15: 0$ iso & $15 \cdot 8$ & $28 \cdot 8$ & $22 \cdot 5$ & $8 \cdot 3$ \\
$15: 0$ anteiso & $3 \cdot 5$ & $0 \cdot 1$ & $4 \cdot 4$ & $\mathrm{NR}$ \\
$15: 0$ iso $2-\mathrm{OH}$ & - & $\mathrm{NR}$ & $16 \cdot 5$ & $\mathrm{NR}$ \\
$15: 0$ iso $3-\mathrm{OH}$ & $2 \cdot 4$ & $3 \cdot 0$ & $3 \cdot 1$ & $2 \cdot 7$ \\
$16: 0$ & $1 \cdot 7$ & $0 \cdot 2$ & $\mathrm{NR}$ & $1 \cdot 1$ \\
$16: 1 \omega 5 c$ & $2 \cdot 1$ & $0 \cdot 8$ & $16 \cdot 9$ & $23 \cdot 3$ \\
$16: 0$ 3-OH & $1 \cdot 3$ & $\mathrm{NR}$ & $\mathrm{NR}$ & $1 \cdot 2$ \\
$16: 0$ iso & $5 \cdot 9$ & $\mathrm{NR}$ & $\mathrm{NR}$ & $2 \cdot 1$ \\
$16: 0$ iso 3-OH & $1 \cdot 2$ & $\mathrm{NR}$ & $\mathrm{NR}$ & $1 \cdot 0$ \\
$16: 1$ iso $\mathrm{H}$ & $4 \cdot 4$ & $0 \cdot 5$ & $\mathrm{NR}$ & $2 \cdot 7$ \\
$17: 0$ iso & $1 \cdot 3$ & $2 \cdot 2$ & $\mathrm{NR}$ & $1 \cdot 7$ \\
$17: 0$ anteiso & $1 \cdot 3$ & $\mathrm{NR}$ & $\mathrm{NR}$ & $\mathrm{NR}$ \\
$17: 0$ iso 3-OH & $10 \cdot 3$ & $6 \cdot 5$ & $12 \cdot 1$ & $5 \cdot 8$ \\
$17: 1 \omega 6 c$ & $5 \cdot 6$ & $1 \cdot 4$ & $5 \cdot 1$ & $1 \cdot 1$ \\
$17: 1$ iso $\omega 9 c$ & $1 \cdot 0$ & $\mathrm{NR}$ & $\mathrm{NR}$ & $\mathrm{NR}$ \\
$18: 1$ iso $\mathrm{H}$ & $3 \cdot 1$ & $\mathrm{NR}$ & $\mathrm{NR}$ & $\mathrm{NR}$ \\
Summed feature $3^{*}$ & - & $14 \cdot 7$ & $\mathrm{NR}$ & $29 \cdot 8 \dagger$ \\
Summed feature $4^{*}$ & $36 \cdot 7$ & $31 \cdot 3$ & $11 \cdot 2 \ddagger$ & $18 \cdot 5 \ddagger$ \\
& & & & \\
\hline
\end{tabular}

${ }^{\star}$ Summed features contain two or three fatty acids that could not be separated by the MIDI system. Summed feature 3 consists of $15: 0$ iso $2-\mathrm{OH}, 16: 1 \omega 7 c$ and/or $16: 1 \omega 7 t$; summed feature 4 consists of $17: 1$ iso $\mathrm{I} /$ anteiso $\mathrm{B}$.

$\dagger$ Reported as summed feature 4 .

$\ddagger$ Reported as summed feature 5 . the almost-complete sequence ( $1401 \mathrm{bp}$ continuous stretch) of the 16S rRNA gene of strain SRC-1 $1^{\mathrm{T}}$ using CLUSTAL_X (Thompson et al., 1997) and edited manually. The confidence value for the aligned dataset was obtained by bootstrap analysis of 1000 replications using SEQBOOT (PHYLIP package; Felsenstein, 1993). Pairwise evolutionary distances were computed using the DNADIST (distance-matrix) program with the Kimura two-parameter model (Kimura, 1980). Phylogenetic trees were constructed using the neighbour-joining and UPGMA methods in the NEIGHBOR program and also by using the TREECONW package (Van de Peer \& De Wachter, 1997). A consensus tree was constructed from multiple trees by using the CONSENSE program.

Phylogenetic analyses, based on 16S rRNA gene sequences, indicated that strain SRC-1 ${ }^{\mathrm{T}}$ belonged to the family 'Flexibacteraceae', showing greatest similarity $(95.5 \%)$ to Pontibacter actiniarum KMM $6156^{\mathrm{T}}$ (Nedashkovskaya et al., 2005), followed by Adhaeribacter aquaticus MBRG1. $5^{\mathrm{T}}$ (89.0 \%; Rickard et al., 2005), Hymenobacter roseosalivarius DSM $11622^{\mathrm{T}}$ (88.9\%; Hirsch et al., 1998) and Hymenobacter actinosclerus CCUG $39621^{\mathrm{T}}$ (88.5\%; Collins et al., 2000). The 16S rRNA gene sequence of two species of Hymenobacter mentioned above and that of strain SRC- $1^{\mathrm{T}}$ showed significant dissimilarity between nucleotides 188 and 231 (nucleotide numbering according to Escherichia coli), and this stretch of the sequence was not considered in similarity comparisons. The phylogenetic tree created by using the neighbour-joining method placed strain SRC $-1^{\mathrm{T}}$ in a clade with $P$. actiniarum (with a bootstrap value of 100 ), forming a cluster with Adhaeribacter, Hymenobacter and Taxeobacter species (Fig. 1). Irrespective of the methods used, the overall topologies of the trees were very similar.

The DNA-DNA relatedness among these genera is assumed to be quite low, as none of the most closely related species showed a high level of 16S rRNA gene sequence similarity, and, according to accepted criteria, differences of more than $3 \%$ at the $16 \mathrm{~S}$ rRNA gene sequence level represent similarities of less than $70 \%$ at the whole-genome level (Stackebrandt \& Goebel, 1994). Strain SRC-1 $1^{\mathrm{T}}$ showed 16S rRNA gene sequence similarity of $95.5 \%$ to $P$. actiniarum KMM $6156^{\mathrm{T}}$, which is close to the proposed threshold (95\%) for the description of a novel genus (Ludwig et al., 1998); however, there are significant phenotypic differences (Table 1). The cell morphology of SRC-1 ${ }^{\mathrm{T}}$ differed from that of the closely related species $P$. actiniarum in having an irregular rod shape; in addition, cells of SRC- $1^{\mathrm{T}}$ are nonmotile. $P$. actiniarum and strain $\mathrm{SRC}-1^{\mathrm{T}}$ also differed regarding the hydrolysis of casein and starch. The fatty acid compositions also differed, with strain SRC $-1^{\mathrm{T}}$ containing significant quantities of $16: 0$ iso $(5 \cdot 9 \%)$ and $18: 1$ iso $\mathrm{H}$ $(3 \cdot 1 \%)$, which were absent in P. actiniarum. One of the predominant fatty acids of $P$. actiniarum was summed feature 3 (15: 0 iso $2-\mathrm{OH}, 16: 1 \omega 7 c$ and/or $16: 1 \omega 7 t)(14 \cdot 7 \%)$, which was absent in strain SRC- $1^{\mathrm{T}}$ (Table 2). These two bacteria also differed in antibiotic sensitivity and DNA G $+C$ content (Table 1). Although strain SRC-1 ${ }^{\mathrm{T}}$ shares some biochemical 


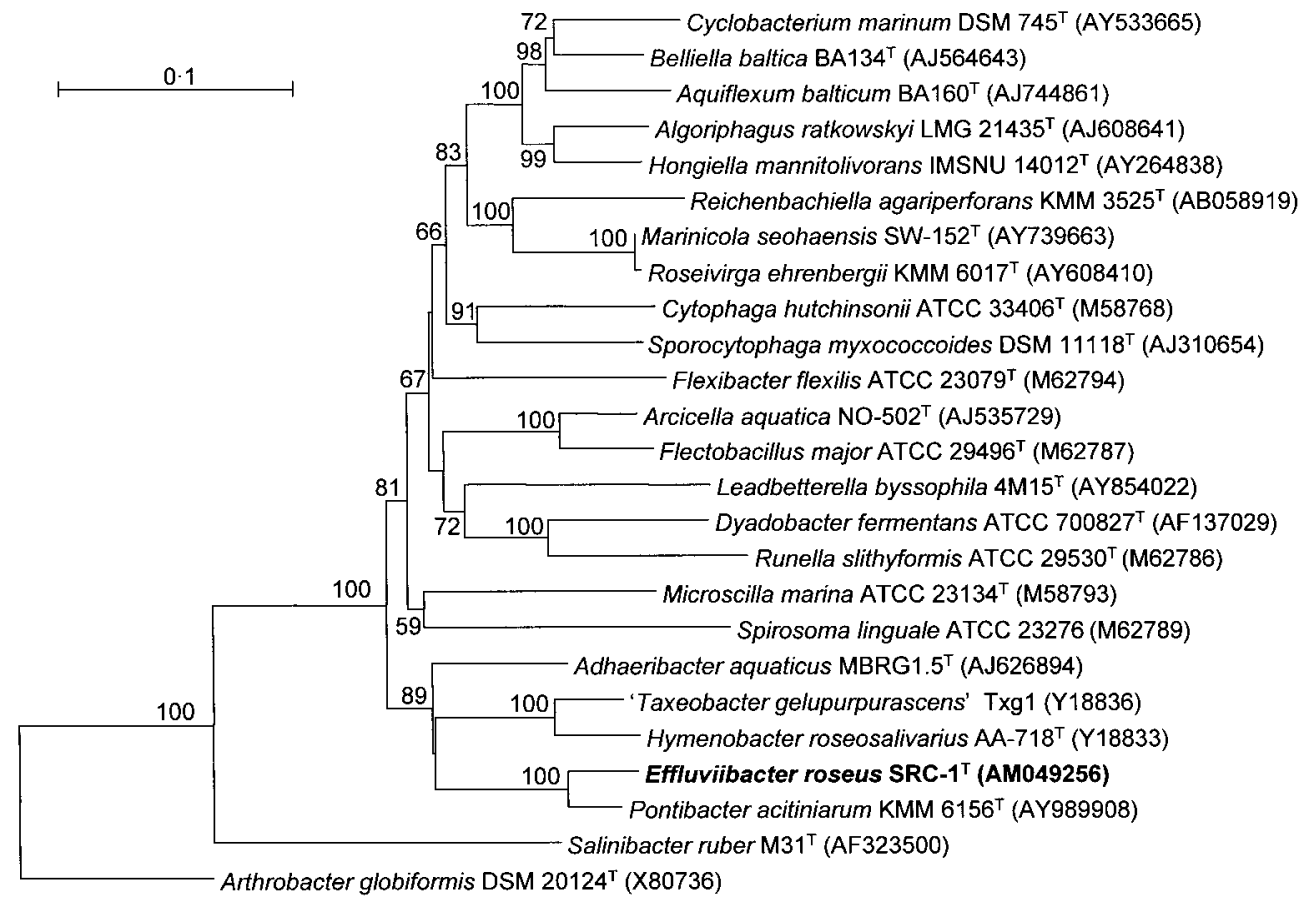

Fig. 1. Neighbour-joining tree, based on $16 \mathrm{~S}$ rRNA gene sequences, showing the phylogenetic relationship between strain $\mathrm{SRC}-1^{\top}$ and genera of the family 'Flexibacteraceae' of the phylum Bacteroidetes. Bootstrap values greater than $50 \%$ are given at nodes. Salinibacter ruber $\mathrm{M}-31^{\top}$ and Arthrobacter globiformis DSM $20124^{\top}$ were used as outgroups. Bar, $0 \cdot 1$ substitutions per site.

characteristics with Adhaeribacter aquaticus, the $16 \mathrm{~S}$ rRNA gene sequence similarity was quite low $(89 \cdot 0 \%)$. Moreover, they differed from each other in genomic $\mathrm{G}+\mathrm{C}$ content (Table 1). Thus, on the basis of phenotypic, chemotaxonomic and phylogenetic characteristics, it is proposed that strain SRC $-1^{\mathrm{T}}$ be recognized as belonging to a novel genus within the family 'Flexibacteraceae', for which the name Effluviibacter gen. nov. is proposed. The genus contains a single species, the type species Effluviibacter roseus sp. nov., of which SRC- $1^{\mathrm{T}}$ is the type strain.

\section{Description of Effluviibacter gen. nov.}

Effluviibacter (Ef.flu.vi.i.bac'ter. L. neut. n. effluvium outflow; N.L. masc. n. bacter rod; N.L. masc. n. Effluviibacter rod from an outflow, referring to the source of isolation of the first strain).

Cells are Gram-negative, non-motile, irregular rods. Obligate aerobes. Oxidase- and catalase-positive. The predominant whole-cell fatty acids are 17:1 iso I/anteiso B (summed feature 4$)(36 \cdot 7 \%$ in the type strain of the type species), $15: 0$ iso $(15 \cdot 8 \%)$ and $17: 0$ iso $3-\mathrm{OH}(10 \cdot 3 \%)$. On the basis of $16 \mathrm{~S}$ rRNA gene sequence analysis, the genus belongs to the family 'Flexibacteraceae' of the phylum Bacteroidetes. Effluviibacter roseus is the type species.

\section{Description of Effluviibacter roseus sp. nov.}

Effluviibacter roseus (ro'se.us. L. masc. adj. roseus rosecoloured, pink).

Exhibits the following features in addition to those listed in the description of the genus. Cells are non-sporulating, irregular rods, $1 \cdot 0-3 \cdot 0 \mu \mathrm{m}$ in length and $0 \cdot 3-0 \cdot 5 \mu \mathrm{m}$ in width. Colonies on nutrient agar are dark pink, circular, convex, smooth and $2-3 \mathrm{~mm}$ in diameter after incubation for 6-8 days. Grows at $4-37^{\circ} \mathrm{C}$, but not at $42{ }^{\circ} \mathrm{C}$, and at $\mathrm{pH} 6 \cdot 0-10 \cdot 0$. Tolerates up to $8 \% \mathrm{NaCl}$. Positive in methyl red, amylase, protease, lysine decarboxylase and ornithine decarboxylase tests but is negative for arginine dihydrolase. Hydrolyses starch and gelatin but not urea, Tween 20 or aesculin. Does not reduce nitrate to nitrite and is negative in the Voges-Proskauer test and for indole production, citrate utilization and $\mathrm{H}_{2} \mathrm{~S}$ production. Utilizes D-fructose, D-galactose, D-glucose, lactose, raffinose and sucrose but not acetate, adonitol, arabinose, citrate, fumarate, lactate, myo-inositol, salicin, sorbitol or succinate as sole sources of carbon. Assimilates histidine, L-isoleucine, L-lysine, ornithine, L-proline and glycine as sole nitrogen sources, but not L-arginine, DL-alanine or L-methionine. Produces acid from D-glucose but not from lactose or sucrose. Resistant to penicillin and tobramycin but sensitive to vancomycin, lincomycin, streptomycin, gentamicin and 
chlortetracycline. The whole-cell fatty acids are listed in Table 2. The major respiratory quinone is MK-7. The phospholipids present are phosphatidylglycerol, diphosphatidylglycerol and an unknown phospholipid. The DNA $\mathrm{G}+\mathrm{C}$ content of the type strain is $59 \cdot 5 \mathrm{~mol} \%$.

The type strain, SRC $-1^{\mathrm{T}}\left(=\right.$ MTCC $7260^{\mathrm{T}}=$ DSM $\left.17521^{\mathrm{T}}\right)$, was isolated from muddy water from an occasional drainage system in Chandigarh, India.

\section{Acknowledgements}

We thank Professor Dr Hans G. Trüper (Institute for Microbiology and Biotechnology, Rheinische Friedrich-Wilhelm-University, Bonn, Germany) for his suggestion as to the Latin nomenclature for the novel genus. We would like to thank Mr Pradipta Saha (Institute of Microbial Technology) for useful discussions. Financial assistance from DBT, Government of India and CSIR are duly acknowledged. This is communication number 046/2005 of the Institute of Microbial Technology.

\section{References}

Bowman, J. P., McCammon, S. A., Brown, M. V., Nichols, D. S. \& McMeekin, T. A. (1997). Diversity and association of psychrophilic bacteria in Antarctic sea ice. Appl Environ Microbiol 63, 3068-3078.

Bowman, J. P., Nichols, C. M. \& Gibson, J. A. E. (2003). Algoriphagus ratkowskyi gen. nov., sp. nov., Brumimicrobium glaciale gen. nov., sp. nov., Cryomorpha ignava gen. nov., sp. nov., and Crocinitomix catalasitica gen. nov., sp. nov., novel flavobacteria isolated from various polar habitats. Int J Syst Evol Microbiol 53, 1343-1355.

Brettar, I., Christen, R. \& Hofle, M. G. (2004). Belliella baltica gen. nov., sp. nov., a novel marine bacterium of the CytophagaFlavobacterium-Bacteroides group isolated from surface water of the central Baltic Sea. Int J Syst Evol Microbiol 54, 65-70.

Buczolits, S., Denner, E. B., Vybiral, D., Wieser, M., Kämpfer, P. \& Busse, H. J. (2002). Classification of three airborne bacteria and proposal of Hymenobacter aerophilus sp. nov. Int J Syst Evol Microbiol 52, 445-456.

Collins, M. D., Pirouz, T., Goodfellow, M. \& Minnikin, D. E. (1977). Distribution of menaquinones in actinomycetes and corynebacteria. J Gen Microbiol 100, 221-230.

Collins, M. D., Huston, R. A., Grant, I. R. \& Patterson, M. F. (2000). Phylogenetic characterization of a novel radiation-resistant bacterium from irradiated pork: description of Hymenobacter actinosclerus sp. nov. Int J Syst Evol Microbiol 50, 731-734.

Felsenstein, J. (1993). PHYLIP (phylogeny inference package), version 3.5c. Distributed by the author. Department of Genome Sciences, University of Washington, Seattle, USA.

Garrity, G. M. \& Holt, J. G. (2001). The road map to the Manual. In Bergey's Manual of Systematic Bacteriology, 2nd edn, vol. 1, pp. 119-166. Edited by D. R. Boone, R. W. Castenholz \& G. M. Garrity. New York: Springer.

Hirsch, P., Ludwig, W., Hethke, C., Sittig, M., Hoffmann, B. \& Gallilowski, C. A. (1998). Hymenobacter roseosalivarius gen. nov., sp. nov. from continental Antarctic soils and sandstone: bacteria of the Cytophaga/Flavobacterium/Bacteroides line of phylogenetic descent. Syst Appl Microbiol 21, 374-383.

Kimura, M. (1980). A simple method for estimating evolutionary rates of base substitutions through comparative studies of nucleotide sequences. J Mol Evol 16, 111-120.
Lanyi, B. (1987). Classical and rapid identification methods for medically important bacteria. Methods Microbiol 19, 1-67.

Ludwig, W. \& Klenk, H.-P. (2001). Overview: a phylogenetic backbone and taxonomic framework for prokaryotic systematics. In Bergey's Manual of Systematic Bacteriology, 2nd edn, vol. 1, pp. 49-65. Edited by D. R. Boone, R. W. Castenholz \& G. M. Garrity. New York: Springer.

Ludwig, W., Strunk, O., Klugbauer, S., Klugbauer, N., Weizenegger, M., Neumaier, J., Bachleitner, M. \& Schleifer, K. H. (1998). Bacterial phylogeny based on comparative sequence analysis. Electrophoresis 19, 554-568.

Mandel, M. \& Marmur, J. (1968). Use of ultraviolet absorbancetemperature profile for determining the guanine plus cytosine content of DNA. Methods Enzymol 12B, 195-206.

Nedashkovskaya, O. I., Suzuki, M., Vysotskii, M. V. \& Mikhailov, V. V. (2003). Reichenbachia agariperforans gen. nov., sp. nov., a novel marine bacterium in the phylum Cytophaga-FlavobacteriumBacteroides. Int J Syst Evol Microbiol 53, 81-85.

Nedashkovskaya, O. I., Kim, S. B., Suzuki, M. \& 9 other authors (2005). Pontibacter actiniarum gen. nov., sp. nov., a novel member of the phylum 'Bacteroidetes', and proposal of Reichenbachiella gen. nov. as a replacement for the illegitimate, prokaryotic generic name Reichenbachia Nedashkovskaya et al. 2003. Int J Syst Evol Microbiol 55, 2583-2588.

Pandey, K. K., Mayilraj, S. \& Chakrabarti, T. (2002). Pseudomonas indica sp. nov., a novel butane-utilizing species. Int J Syst Evol Microbiol 52, 1559-1567.

Rickard, A. H., Stead, A. T., O’May, G. A., Lindsay, S., Banner, M., Handley, P. S. \& Gilbert, P. (2005). Adhaeribacter aquaticus gen. nov., sp. nov., a Gram-negative isolate from a potable water biofilm. Int J Syst Evol Microbiol 55, 821-829.

Shivaji, S., Rao, N. S., Saisree, L., Reddy, G. S. N., Seshu Kumar, G. \& Bhargava, P. M. (1989). Isolates of Arthrobacter from the soils of Schirmacher Oasis, Antarctica. Polar Biol 10, 225-229.

Smibert, R. M. \& Krieg, N. R. (1994). Phenotypic characterization. In Methods for General and Molecular Bacteriology, pp. 607-654. Edited by P. Gerhardt, R. G. E. Murray, W. A. Wood \& N. R. Krieg. Washington, DC: American Society for Microbiology.

Stackebrandt, E. \& Goebel, B. M. (1994). Taxonomic note: a place for DNA-DNA reassociation and 16S rRNA sequence analysis in the present species definition in bacteriology. Int J Syst Bacteriol 44, 846-849.

Suresh, K., Reddy, G. S. N., Sengupta, S. \& Shivaji, S. (2004a). Deinococcus indicus sp. nov., an arsenic-resistant bacterium from an aquifer in West Bengal, India. Int J Syst Evol Microbiol 54, 457-461.

Suresh, K., Prabagaran, S. R., Sengupta, S. \& Shivaji, S. (2004b). Bacillus indicus sp. nov., an arsenic-resistant bacterium isolated from an aquifer in West Bengal, India. Int J Syst Evol Microbiol 54, 1369-1375.

Tamaoka, J., Katayama-Fujimura, Y. \& Kuraishi, H. (1983). Analysis of bacterial menaquinone mixtures by high performance liquid chromatography. J Appl Bacteriol 54, 31-36.

Thompson, J. D., Gibson, T. J., Plewniak, F., Jeanmougin, F. \& Higgins, D. G. (1997). The CLUSTAL_X windows interface: flexible strategies for multiple sequence alignment aided by quality analysis tools. Nucleic Acids Res 25, 4876-4882.

Van de Peer, Y. \& De Wachter, R. (1997). Construction of evolutionary distance trees with TREECON for Windows: accounting for variation in nucleotide substitution rate among sites. Comput Appl Biosci 13, 227-230.

Yi, H. \& Chun, J. (2004). Hongiella mannitolivorans gen. nov., sp. nov., Hongiella halophila sp. nov. and Hongiella ornithinivorans sp. nov., isolated from tidal flat sediment. Int J Syst Evol Microbiol 54, 157-162. 